\title{
Hepatitis G RNA Measurement
}

National Cancer Institute

\section{Source}

National Cancer Institute. Hepatitis G RNA Measurement. NCI Thesaurus. Code $C 92272$.

The determination of the amount of Hepatitis G RNA present in a sample. 